\title{
Pharmacokinetics of intravitreal antibiotics in endophthalmitis
}

\author{
Medikonda Radhika', Kopal Mithal', Abhishek Bawdekar ${ }^{1}$, Vivek Dave², Animesh Jindal', Nidhi Relhan, \\ Thomas Albini ${ }^{3}$, Avinash Pathengay ${ }^{1 *}$ and Harry W Flynn $\mathrm{Jr}^{3}$
}

\begin{abstract}
Intravitreal antibiotics are the mainstay of treatment in the management of infectious endophthalmitis. Basic knowledge of the commonly used intravitreal antibiotics, which includes their pharmacokinetics, half-life, duration of action and clearance, is essential for elimination of intraocular infection without any iatrogenic adverse effect to the ocular tissue. Various drugs have been studied over the past century to achieve this goal. We performed a comprehensive review of the antibiotics which have been used for intravitreal route and the pharmacokinetic factors influencing the drug delivery and safety profile of these antibiotics. Using online resources like PubMed and Google Scholar, articles were reviewed. The articles were confined to the English language only. We present a broad overview of pharmacokinetic concepts fundamental for use of intravitreal antibiotics in endophthalmitis along with a tabulated compendium of the intravitreal antibiotics using available literature. Recent advances for increasing bioavailability of antibiotics to the posterior segment with the development of controlled drug delivery devices are also described.
\end{abstract}

Keywords: Intravitreal; Antibiotics; Pharmacokinetics; Endophthalmitis

\section{Review}

Introduction

Endophthalmitis whether exogenous or endogenous is anatomically and visually devastating for the patient and always presents a challenge to the treating physician. The vitreous is a transparent gelatinous avascular body, rich in collagen and hyaluronic acid, which provides a good culture medium for the microorganisms to proliferate. The presence of poorly developed local immune mechanisms also promotes microbial proliferation. For successful elimination of the infection in endophthalmitis, antibiotics must reach the intraocular space and adjacent ocular tissues. Static and dynamic ocular barriers which form part of the natural protective mechanisms of the eye impede the penetration of systemically and topically administered antibiotics. Satisfactory drug concentration in the vitreous can be achieved only by the intravitreal route. Over the years, intravitreal administration

\footnotetext{
* Correspondence: avinash@lvpei.org

'Retina and Uveitis Department, L V Prasad Eye Institute, GMR Varalaxmi Campus, 11-113/1, Hanumantha waka Junction, Visakhapatnam, Andhra Pradesh 530040, India

Full list of author information is available at the end of the article
}

of antibiotics has become the mainstay of endophthalmitis management [1,2]. In the absence of adequate antimicrobial concentrations, irreversible tissue destruction ensues [3].

Various factors are responsible for the poor penetration of topical and systemic antibiotics in the vitreous. Baring a few exceptions like systemically administered fluoroquinolones and linezolid [3-5], topical and systemic antibiotics do not achieve adequate therapeutic levels due to various physiological barriers. Topically instilled medicines are diluted by the tear film, causing loss of significant drug in the lacrimal flow [6]. Further low molecular weight antibiotics also undergo systemic absorption from the conjunctival capillaries and the nasolacrimal mucosal surfaces, leading to further drop in bioavailability [7]. The corneal epithelium also has tight junctions, leading to poor paracellular drug penetration especially for ionic drugs [8]. The posterior barrier between the bloodstream and the eye is comprised of retinal pigment epithelium (RPE) and the tight walls of retinal capillaries. Unlike retinal capillaries, the vasculature of the choroid has extensive blood flow and leaky walls. Systemically administered drugs easily gain access to the choroidal extravascular space, but thereafter, 
distribution into the intraocular space via the retina is limited by the RPE and the retinal endothelium [9]. Thus, intravitreal administration serves as the only direct access to the vitreous cavity by bypassing the blood retinal barrier and achieving higher concentrations of drugs for prolonged periods of time [10].

Using online resources like PubMed and Google Scholar, articles of the antibiotics which have been used for intravitreal route and the pharmacokinetic factors influencing the drug delivery and safety profile of these antibiotics were reviewed. The articles were limited to the English language only. The keywords searched were endophthalmitis, intravitreal antibiotics and pharmacokinetics.

\section{History of intravitreal antibiotics}

Experimental studies for treatment of endophthalmitis in rabbit eyes with intraocular antibiotics like penicillin and sulphonamides were reported as early as the 1940s [11]. Intravitreal penicillin was found to have a favourable though limited effect on traumatic endophthalmitis in these studies. In the 1970s, Peyman and associates reported the safety and efficacy of various intravitreal antibiotics in experimentally induced endophthalmitis in rabbit eyes and established the recommended doses of various intravitreal antibiotics in human eyes [12,13]. Favourable results of treatment of acute postoperative endophthalmitis with intravitreal antibiotics - vancomycin for staphylococcal endophthalmitis and aminoglycosides for Gram-negative endophthalmitis - were reported during the 1970s [13-15]. However, as the macular toxicity of aminoglycoside antibiotics became known, ceftazidime, a thirdgeneration cephalosporin, has become the preferred alternative [16]. In recent times, alternate antibiotics like intravitreal piperacillin-tazobactam have been studied both in animal models and clinically especially in cases of Enterobacter species and multidrug-resistant Pseudomonas endophthalmitis with favourable outcomes and have emerged as a useful alternative to ceftazidime [17-19].

\section{Factors influencing antibiotic pharmacokinetics}

Intravitreal injection of antibiotics bypasses the various anatomical and physiological ocular barriers. The drug diffuses freely in the vitreous cavity and reaches the retinal surface, facilitated by extraocular movements [20]. However, the drug distribution and clearance from the vitreous are influenced by various factors including ionic nature, molecular weight of the drug molecule, surgical status and effect of ocular inflammation. In order to achieve a sustained therapeutic drug concentration in the vitreous, the frequency of administration should be based on the half-life $\left(t_{1 / 2}\right)$. The elimination of drug usually follows first-order kinetics and is proportional to the amount of drug available and the volume of the vitreous.
Factors influencing the pharmacokinetics of intravitreal antibiotics have been described below briefly [21].

1. Route of exit: Drug molecules can leave the eye through the anterior route or the posterior route. Large molecules are known to leave the eye predominantly by the passive diffusion across the vitreous to the anterior chamber and through Schlemm's canal. These include vancomycin, aminoglycosides, macrolides and rifampicin. The posterior route is achieved by active transport in the capillaries and the retinal pigment epithelium through which smaller drug molecules like beta-lactams, clindamycin and fluoroquinolones are cleared [22].

2. Ionic nature: Cationic drugs like vancomycin, aminoglycosides, erythromycin and rifampicin undergo clearance by passive diffusion into the aqueous and leave the eye via the anterior chamber with a $t_{1 / 2}$ of about $24 \mathrm{~h}$ [23-25]. Anionic drugs like beta-lactams, cephalosporins and clindamycin primarily undergo clearance more rapidly across the blood retinal barrier via the posterior route and exit the eye via uveal blood flow [23,24]. This is facilitated by active transport by the retinal pigment layer pump. Hence, they have shorter $t_{1 / 2}$ of about $8 \mathrm{~h}$. Fluoroquinolones which are zwitterions are cleared via both routes and hence have the shortest $t_{1 / 2}[26,27]$.

3. Solubility coefficient of the drug: Lipophilic antibiotics like fluoroquinolones and chloramphenicol can be transported by passive diffusion, while water-soluble antibiotics like beta-lactams leave the eye via active transport $[23,24]$.

4. Status of ocular inflammation: In a non-inflamed eye, the anterior route is poorly efficient, and hence, antibiotics (vancomycin, aminoglycosides, erythromycin and rifampicin) eliminated by this route show long half-life values. Thus, drugs eliminated through the anterior route have a faster clearance in an inflamed eye [25]. For drugs mainly eliminated by the posterior route (beta-lactams, cephalosporins and clindamycin) in the case of an inflamed eye, the drug clearance is retarded due to compromise of the retinal pigment epithelial (RPE) pump or the active transport. Thus, their half-life is extended [24,28-30].

5. Surgical status of the eye: Clearance of antibiotics which leave the eye through the anterior route is more rapid in aphakic eyes, while those which leave the eye primarily through the posterior route are cleared more rapidly in vitrectomized eyes. Hegazy et al. demonstrated retinal toxicity to routinely used doses of intravitreal antibiotics in silicone oil-filled eyes. Retinal toxicity was hypothesized due to reduction of the preretinal space; the drug is confined to the 
limited aqueous-filled space surrounding the oil bubble and has a longer elimination time. They recommended using one quarter of the recommended dose to prevent retinal toxicity [31].

6. Molecular weight: It has been found that the retention of the drug in the vitreous cavity increases with increase in relative impermeability of the retina. As most drugs have a molecular weight of $<500 \mathrm{Da}$, the half-life is less than $72 \mathrm{~h}$, requiring repeat injection at that interval depending on the clinical situation [29].

7. Vitreous liquefaction: If vitreous liquefaction occurs in the anterior few millimetres and the posterior few millimetres of the globe, it can lead to the quick egress of the drug out of the eye, leading to shortening of its half-life [29].

8. Solution density: If the density of the injected solution is greater than water, it may settle down under gravity and cause localized toxicity. This may require intermittent repositioning of the patient's head to avoid such an eventuality [32].

9. Frequency of intravitreal antibiotic administration: The parameters deciding the frequency of repeat administration of antibiotics are clinical response, half-life, drug clearance from the eye and surgical status of the eye. The aim of repeat dosing should be to optimize the duration of drug exposure to concentrations above the minimum inhibitory concentration (MIC), rather than to aim at higher peak levels. Adequate and safe antibiotic levels can be better achieved by more frequent rather than higher dosages [28].

\section{Intravitreal antibiotics: dosing and frequency}

Table 1 is a pooled compendium of all published information pertaining to the dosing of antibiotics studied and used for intraocular use in treating experimental endophthalmitis and human eyes [16-59].

\section{Preparation of intravitreal antibiotics}

Since the recommended therapeutic dosage of intravitreal antibiotics is very small and carefully titrated to prevent retinal toxicity, it is important that this dose is maintained each time an injection is prepared [39]. Standard protocols have to be followed to ensure accuracy, precision as well as reproducibility. The injections have to be prepared under strict aseptic conditions, under a certified laminar flow by trained personnel. Preferably, a printed reference display sheet should be consulted while preparing injections every time as dilution errors may be toxic. Mehta et al. reported that vancomycin, ceftazidime and moxifloxacin prepared in single-use polypropylene syringes retain potency, sterility and stability up to 24 weeks when stored at $-20^{\circ} \mathrm{C}$ or $-80^{\circ} \mathrm{C}[60]$.

\section{Antibiotic resistance}

Indiscriminate and injudicious use and abuse of antibiotics have led to the development of resistant bacterial strains. These include the ocular and nasopharyngeal flora as well as pathogenic organisms like those causing keratitis and other ocular infections. Endophthalmitis caused by these organisms is associated with more severe clinical course and worse visual outcomes [60-62]. This problem of emergence of resistance to standard antibiotic therapy has forced clinicians to continually evaluate the best intraocular antibiotics available for the treatment of bacterial endophthalmitis. In such situations, the choice of antibiotics is judiciously guided by culture results and sensitivity patterns of the causative organism. However, it is also known that in vitro resistance need not be mirrored with in vivo sensitivity and routinely administered antibiotic doses provide intraocular drug concentrations which are much higher than the MICs of most pathogens [61,62]. Knowledge of pharmacokinetics, susceptibility patterns and minimum inhibitory concentration serves to properly predict the in vivo efficacy of antibiotics against target pathogens [62].

\section{Combination therapy}

Combination intravitreal therapy is used often in polymicrobial cases or in empirical treatment of endophthalmitis [74]. The physicochemical properties of the various drugs used for combined injections should be well known by the physician as they form the basis of possible adverse drug interactions. The two most common physicochemical entities that can cause adverse drug interactions are dilution-dependent reactions and acidbase reactions. Adverse reactions when they occur become evident by physical changes like precipitates, effervescence, haziness and viscosity changes. Precipitates are avoided by injecting the drugs through different syringes. Still, the development of subclinical microprecipitates cannot be ruled out. It has been reported that such precipitate formation may still allow enough antibacterial activity of the drug at intravitreal concentrations to be therapeutically active [75]. Changes in individual drug half-life post multiple injection have not been studied in literature.

\section{Future trends}

Advances in ocular drug delivery system research are expected to provide new tools for the treatment of posterior segment diseases, providing improved drug penetration, prolonged action, higher efficacy, improved safety and less invasive administration, resulting in higher patient compliance. Various attempts have been made to improve drug bioavailability by increasing both drug retention and drug penetration. Patient compliance and comfort considerations in drug administration are very important factors 
Table 1 Pharmacokinetics of intravitreal antibiotics - recommended dosing and frequency of administration

\begin{tabular}{|c|c|c|c|c|c|c|c|c|c|}
\hline \multirow{2}{*}{$\begin{array}{l}\text { Serial } \\
\text { number }\end{array}$} & \multirow[t]{2}{*}{ Drug } & \multirow[t]{2}{*}{ Model } & \multirow{2}{*}{$\begin{array}{l}\text { Recommended } \\
\text { dose }(\mu \mathrm{g} / 0.1 \mathrm{ml})\end{array}$} & \multirow{2}{*}{$\begin{array}{l}\text { Route of } \\
\text { clearance }\end{array}$} & \multicolumn{3}{|c|}{ Half-life $\left(t_{1 / 2}\right)$ in vitreous } & \multirow{2}{*}{$\begin{array}{l}\text { Frequency } \\
\text { of repeat } \\
\text { injections (h) }\end{array}$} & \multirow[t]{2}{*}{ Susceptible microorganisms } \\
\hline & & & & & $\begin{array}{l}\text { Non-inflamed } \\
\text { phakic eyes }\end{array}$ & $\begin{array}{l}\text { Inflamed } \\
\text { eyes }\end{array}$ & $\begin{array}{l}\text { Aphakic vitrectomized } \\
\text { eyes }\end{array}$ & & \\
\hline \multirow[t]{2}{*}{1.} & \multirow[t]{2}{*}{ Amikacin [16,33-35] } & Human & 400 & \multirow[t]{2}{*}{ Anterior } & NA & NA & NA & 24 to 48 & \multirow{2}{*}{$\begin{array}{l}\text { Aerobic GNBs, Pseudomonas } \\
\text { aeruginosa }\end{array}$} \\
\hline & & Rabbit & 400 & & $25.5 \mathrm{~h}$ & $<24 \mathrm{~h}$ & $7 \mathrm{~h}$ & 24 to 48 & \\
\hline 2. & Ampicillin [36] & Human & 5,000 & Posterior & NA & NA & NA & 48 & $\begin{array}{l}\text { GPC, enterobacteria, therapeutic } \\
\text { option for infections caused by } \\
\text { MDR pathogens }\end{array}$ \\
\hline \multirow[t]{2}{*}{3.} & \multirow[t]{2}{*}{ Amphotericin-B [37] } & Human & 5 to 10 & \multirow[t]{2}{*}{ Posterior } & 8.9 days & NA & $1.8 \mathrm{~h}$ & NA & \multirow{2}{*}{$\begin{array}{l}\text { Yeasts, filamentous fungi (resistance } \\
\text { reported for various species of } \\
\text { Aspergillus) }\end{array}$} \\
\hline & & Rabbit & 10 & & 4.7 days & NA & NA & NA & \\
\hline 4. & Aztreonam [38] & Rabbit & 100 & Posterior & $7.5 \mathrm{~h}$ & NA & NA & 12 & $\begin{array}{l}\text { Excellent activity against family } \\
\text { Enterobacteriaceae; moderate } \\
\text { activity against Pseudomonas }\end{array}$ \\
\hline \multirow[t]{2}{*}{5.} & \multirow[t]{2}{*}{ Carbenicillin [24] } & Rabbit & 2,000 & \multirow[t]{2}{*}{ Anterior } & $5 \mathrm{~h}$ & NA & NA & 15 to 24 & \multirow{2}{*}{$\begin{array}{l}\text { Pseudomonas, therapeutic option } \\
\text { for infections caused by MDR } \\
\text { pathogens }\end{array}$} \\
\hline & & Monkey & 1,000 & & $10 \mathrm{~h}$ & NA & NA & NA & \\
\hline \multirow[t]{2}{*}{6.} & \multirow[t]{2}{*}{ Cephazolin $[24,39]$} & Human & 2,250 & \multirow[t]{2}{*}{ Posterior } & $6.5 \mathrm{~h}$ & $10.5 \mathrm{~h}$ & NA & 24 & \multirow[t]{2}{*}{ GPC, GPB, E. coli, Proteus, H. influenza } \\
\hline & & Rabbit & 2,250 & & $6.5 \mathrm{~h}$ & $10.4 \mathrm{~h}$ & $6 \mathrm{~h}$ & NA & \\
\hline \multirow[t]{2}{*}{7.} & \multirow[t]{2}{*}{ Ceftazidime $[16,40]$} & Human & 2,250 & \multirow{2}{*}{$\begin{array}{l}\text { Both posterior } \\
\text { and anterior }\end{array}$} & NA & NA & NA & 48 to 72 & \multirow{2}{*}{$\begin{array}{l}\text { Aerobic GNBs, GPBs including } \\
\text { Pseudomonas }\end{array}$} \\
\hline & & Rabbit & 2,250 & & $13.8 \mathrm{~h}$ & $10.1 \mathrm{~h}$ & $4.7 \mathrm{~h}$ & 72 & \\
\hline 8. & Ceftriaxone $[21,29]$ & Rabbit & 2,000 & $\begin{array}{l}\text { Both posterior } \\
\text { and anterior }\end{array}$ & NA & NA & NA & 48 to 72 & Aerobic GNBs \\
\hline 9. & Cefuroxime $[21,29]$ & $\begin{array}{l}\text { Human } \\
\text { eyes }\end{array}$ & 1,000 & Posterior & NA & NA & NA & 48 to 72 & $\begin{array}{l}\text { GPC, GPB, GNC, GNB including } \\
\text { Pseudomonas aeruginosa, } \\
\text { penicillinase-producing } \\
\text { N. gonorrhoeae, ampicillin-resistant } \\
\text { H. influenzae }\end{array}$ \\
\hline \multirow[t]{2}{*}{10.} & \multirow[t]{2}{*}{ Ciprofloxacin [26,28] } & Human & 100 & \multirow{2}{*}{$\begin{array}{l}\text { Both anterior } \\
\text { and posterior }\end{array}$} & 3.5 to $5.5 \mathrm{~h}$ & NA & $1.2 \mathrm{~h}$ & 12 & \multirow{2}{*}{$\begin{array}{l}\text { Broad-spectrum activity against } \\
\text { aerobic Gram-positive and } \\
\text { Gram-negative bacteria, Actinomyces, } \\
\text { Nocardia spp. }\end{array}$} \\
\hline & & Rabbit & 100 & & $2.2 \mathrm{~h}$ & NA & NA & NA & \\
\hline 11. & Clarithromycin [41] & Rabbit & $<1,000$ & Posterior & $2 \mathrm{~h}$ & NA & NA & NA & $\begin{array}{l}\text { GPC, GPB, Chlamydia, Toxoplasma } \\
\text { gondii }\end{array}$ \\
\hline 12. & Clindamycin [42] & Human & 1,000 & Posterior & $40 \mathrm{~h}$ & NA & NA & 72 & $\begin{array}{l}\text { GPCs - staphylococci, pneumococci; } \\
\text { GPBs - Bacillus; GNBs - Bacteroides, } \\
\text { Fusobacterium; resistance - enterococci, } \\
\text { Enterobacteriaceae, Clostridium, } \\
\text { Toxoplasma gondii }\end{array}$ \\
\hline 13. & Chloramphenicol [43] & Human & 2,000 & Posterior & NA & NA & NA & 24 & $\begin{array}{l}\text { Gram-negative bacteria, Rickettsia, } \\
\text { Borellia recurrentis; moderately } \\
\text { active against Gram-positive }\end{array}$ \\
\hline
\end{tabular}




\begin{tabular}{|c|c|c|c|c|c|c|c|c|c|}
\hline & & & & & & & & & $\begin{array}{l}\text { bacteria and Mycobacterium } \\
\text { tuberculosis }\end{array}$ \\
\hline 14. & Daptomycin [44] & Rabbit & 200 & Posterior & $42 \mathrm{~h}$ & NA & NA & Single dose & $\begin{array}{l}\text { Gram-positive organisms, MRSA, } \\
\text { VRSA, pneumococci, enterococci }\end{array}$ \\
\hline 15. & Dalfopristine/quinopristine [45] & Rabbit & 400 & Posterior & NA & NA & NA & 48 & Active against VRSA \\
\hline 16. & Doxycycline [46] & Rabbit & 125 & NA & NA & NA & NA & NA & $\begin{array}{l}\text { Broad-spectrum - Gram-positive } \\
\text { and Gram-negative bacteria, } \\
\text { Spirochaetes, Rickettsia, Chlamydiae, } \\
\text { Mycoplasma, Actinomyces, Entamoeba } \\
\text { histolytica, atypical mycobacteria }\end{array}$ \\
\hline 17. & Fluconazole [47] & Rabbit & 200 & Posterior & $3.08 \mathrm{~h}$ & NA & NA & NA & Yeasts \\
\hline \multirow[t]{2}{*}{18.} & \multirow[t]{2}{*}{ Gentamicin $[48,49]$} & Human & 200 & Anterior & 40 to $60 \mathrm{~h}$ & 20 to $40 \mathrm{~h}$ & $<40 \mathrm{~h}$ & 72 to 96 & \multirow[t]{2}{*}{ Aerobic GNBs } \\
\hline & & Rabbit & 40 to 70 & & $32 \mathrm{~h}$ & $19 \mathrm{~h}$ & $12 \mathrm{~h}$ & NA & \\
\hline 19. & Imipenem [50] & Rabbit & 50 to 100 & Posterior & NA & NA & NA & NA & $\begin{array}{l}\text { MDR GPB, GNBs including } \\
\text { Psedomonas aeruginosa, } \\
\text { therapeutic option for } \\
\text { infections caused by MDR } \\
\text { pathogens }\end{array}$ \\
\hline 20. & Linezolid [5,51] & Rabbit & 400 & NA & $2 \mathrm{~h}$ & NA & NA & NA & $\begin{array}{l}\text { Aerobic GPC including MRSA and } \\
\text { vancomycin-resistant enterococci }\end{array}$ \\
\hline 21. & Moxifloxacin [52] & Rabbit & 200 & $\begin{array}{l}\text { Both anterior } \\
\text { and posterior }\end{array}$ & $1.72 \mathrm{~h}$ & Prolonged & NA & 12 & $\begin{array}{l}\text { Broad-spectrum activity against } \\
\text { Gram-positive and Gram-negative } \\
\text { organisms }\end{array}$ \\
\hline 22. & Ofloxacin [27] & Rabbit & 200 to 500 & $\begin{array}{l}\text { Both anterior } \\
\text { and posterior }\end{array}$ & $5.6 \mathrm{~h}$ & $9.7 \mathrm{~h}$ & NA & 24 & $\begin{array}{l}\text { Broad-spectrum activity against } \\
\text { Gram-positive and Gram-negative } \\
\text { organisms }\end{array}$ \\
\hline 23. & Penicillin [11] & Human & 2 to 4,000 units & Posterior & NA & NA & NA & 48 & $\begin{array}{l}\text { Broad-spectrum activity against } \\
\text { Gram-positive organisms, Spirochaetes }\end{array}$ \\
\hline \multirow[t]{2}{*}{24.} & \multirow{2}{*}{$\begin{array}{l}\text { Piperacillin/tazobactam } \\
\text { [17-19] }\end{array}$} & Human & 225 & \multirow[t]{2}{*}{ Posterior } & NA & NA & NA & NA & \multirow{2}{*}{$\begin{array}{l}\text { Effective GNBs, Staphylococcus } \\
\text { epidermidis and Pseudomonas } \\
\text { aeruginosa; therapeutic option for } \\
\text { infections caused by MDR } \\
\text { pathogens }\end{array}$} \\
\hline & & Rabbit & $<250$ & & NA & NA & NA & NA & \\
\hline 25. & $\begin{array}{l}\text { Sulfamethoxazole/ } \\
\text { trimethoprim [52] }\end{array}$ & Rabbit & 1,600 trimethoprim & Anterior & NA & NA & NA & NA & $\begin{array}{l}\text { Broad-spectrum antibacterial activity; } \\
\text { Toxoplasma gondii }\end{array}$ \\
\hline \multirow[t]{2}{*}{26.} & \multirow[t]{2}{*}{ Tobramycin [53] } & Human & 200 to 400 & Anterior & NA & NA & NA & NA & \multirow[t]{2}{*}{ Aerobic Gram-negative organisms } \\
\hline & & Rabbit & 750 & & NA & NA & NA & 72 to 96 & \\
\hline 27. & Trovafloxacin [54] & Rabbit & 25 & $\begin{array}{l}\text { Both anterior } \\
\text { and posterior }\end{array}$ & NA & NA & NA & 24 to 48 & $\begin{array}{l}\text { Expanded spectrum against } \\
\text { Gram-positive and } \\
\text { Gram-negative bacteria }\end{array}$ \\
\hline \multirow[t]{2}{*}{28.} & \multirow[t]{2}{*}{ Vancomycin $[25,55-57]$} & Human & 1,000 & Anterior & 25.5 to $56 \mathrm{~h}$ & $48 \mathrm{~h}$ & 9.8 h & 72 & \multirow{2}{*}{$\begin{array}{l}\text { Active against GPCs - MRSA and } \\
\text { MDR Staphylococcus epidermidis }\end{array}$} \\
\hline & & Rabbit & & & $25.1 \mathrm{~h}$ & NA & $8.9 \mathrm{~h}$ & NA & \\
\hline
\end{tabular}


Table 1 Pharmacokinetics of intravitreal antibiotics - recommended dosing and frequency of administration (Continued)

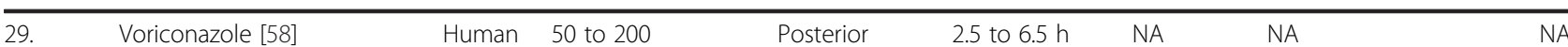

Rabbit 25

Posterior

NA

NA

Broad-spectrum activity against
moulds and yeasts

30. Meropenem [73]

Human Posterior $\quad 2.6 \mathrm{~h}$

Rabbit $\quad 0.5$

$2.6 \mathrm{~h}$

NA

NA

NA

GPC, Gram-positive cocci; GPB, Gram-positive bacilli; GNB, Gram GPC, Gram-positive cocci; GPB, Gram-positive
Staphylococcus aureus; NA, not available. 
that may impact the drug therapeutic efficacy [64]. These attempts can be divided into two main categories: bioavailability improvement and controlled release drug delivery. The first category includes gels, emulsions, viscosity enhancers, pro-drugs, liposomes and iontophoresis. The second category includes various types of polymeric inserts, implants and nanoparticles.

A pro-drug is defined as an inactive species obtained by chemical modifications of the active drug which, when delivered, will release the active drug essentially in a single step (i.e. enzymatic conversion). Usually, ophthalmic pro-drugs are lipophilic esters or diesters with better permeability than the parent compound. Lipophilicity increases uptake of the pro-drug across lipophilic membranes which otherwise act as a barrier to hydrophilic drugs. If the drug is incorporated into a polymeric vehicle which controls the release of the pro-drug, a sustained delivery of the drug to the retina and vitreous layers may be possible [65].

Liposomes are vesicles composed of one or more phospholipid bilayers separated by aqueous compartments. Liposomes can encapsulate hydrophilic drugs in the aqueous cavity or introduce hydrophobic drugs into the membrane as a component. They act as reservoirtype carriers and possess qualities which can make them ideal for certain posterior segment uses [66,67]. Intravitreally administered liposomal systems could both significantly increase drug half-life and minimize the intraocular side effects of drugs used (i.e. ganciclovir and 5-fluorouridine). Intravitreal injection of liposomes containing a lipid pro-drug of ganciclovir inhibited CMV retinitis in rabbits $[68,69]$.

The mechanism of iontophoresis involves applying an electrical current to an ionisable substance to increase its mobility across a surface. The EyeGate II Delivery System (EGDS; EyeGate Pharmaceuticals, Inc., Waltham, MA, USA), a novel iontophoretic system, has been designed to achieve optimal therapeutic levels of drug in the anterior and posterior segments of the eye, while simultaneously minimizing systemic distribution [70]. The system consists of an inert electrode which electrolyzes water to produce hydronium ions. These hydronium ions propel charged drug molecules. Studies demonstrating safety and efficacy profile show promise for the future [71].

Nanoparticles are defined as particles with a diameter of less than $1 \mathrm{~nm}\left(10^{-9} \mathrm{~m}\right)$ consisting of various biodegradable materials, such as natural or synthetic polymers, lipids, phospholipids and metals. Studies have shown that nanoparticles of different sizes and electric charges, when injected into the vitreous, migrate through the retinal layers and tend to accumulate in the retinal pigment epithelium (RPE) cells up to 4 months after a single intravenous injection [72].
Pharmacokinetics, safety and efficacy of newer antibiotics and antifungals need to be continually explored and established in view of the emerging multidrug and sometimes pan-drug resistance amongst organisms causing systemic and ocular infections [62]. For sustained drug delivery and minimizing chances of retinal toxicity, intravitreal drug effects of delivering drugs in liposomes or microspheres have been studied which could provide therapeutic drug levels for up to a month [63,64]. Nonbiodegradable and biodegradable devices or implants have been investigated [65-67]. Utility of pro-drugs, permeability enhancers, particulate drug delivery systems xand iontophoresis is currently being explored for sustained intraocular drug delivery $[66,67]$.

\section{Conclusions}

The management of infectious endophthalmitis has evolved from the usage of systemic antibiotics in the past to the current use of intravitreal antibiotics, paving the way for nanotechnology in drug delivery in the future. Successful management of endophthalmitis could be enhanced by better understanding of pharmacokinetics of intravitreal antibiotics. Emergence of drug resistance amongst bacteria remains a matter of concern.

\section{Competing interests}

The authors declare that they have no competing interests.

\section{Authors' contributions}

$M R, K M$ and $A B$ were involved in the preparation of the manuscript. $M R, K M$, $A B, V D, A J$ and NR were involved in the collection of data. TA, AP and HWFJ corrected the manuscript. All authors read and approved the final manuscript.

\section{Disclosures}

Dr. Albini receives consulting honoraria from Bausch \& Lomb, Allergan, ThomboGenics and Eleven Biotherapeutics. Dr. Flynn receives research support from Saten Pharmaceutical Co. and Vindico Medical Education.

\section{Author details}

${ }^{1}$ Retina and Uveitis Department, L V Prasad Eye Institute, GMR Varalaxmi Campus, 11-113/1, Hanumantha waka Junction, Visakhapatnam, Andhra Pradesh 530040, India. ${ }^{2}$ Srimati Kannuri Santhamma Centre for Vitreoretinal Diseases, L V Prasad Eye Institute, KAR Campus, Hyderabad, Andhra Pradesh 500034, India. ${ }^{3}$ Department of Ophthalmology, Bascom Palmer Eye Institute, Miami, FL 33136, USA

Received: 27 February 2014 Accepted: 21 July 2014

Published online: 10 September 2014

\section{References}

1. Peyman GA, Schulman JA (1989) Intravitreal drug therapy. Jpn J Ophthalmol 33(4):392-404

2. Baum J, Peyman GA, Barza M (1982) Intravitreal administration of antibiotic in the treatment of bacterial endophthalmitis. III. Consensus. Surv Ophthalmol 26(4):204-206

3. Snyder RW, Glasser DB (1994) Antibiotic therapy for ocular infection. West $J$ Med 161(6):579-584

4. García-Sáenz MC, Arias-Puente A, Fresnadillo-Martinez MJ, Carrasco-Font C (2001) Human aqueous humor levels of oral ciprofloxacin, levofloxacin, and moxifloxacin. J Cataract Refract Surg 27(12):1969-1974

5. Fiscella RG, Lai WW, Buerk B (2004) Aqueous and vitreous penetration of linezolid (Zyvox) after oral administration. Ophthalmology 111(6):1191-1195 
6. Urtti A, Salminen L (1993) Minimizing systemic absorption of topically administered ophthalmic drugs. Surv Ophthalmolol 37:435-457

7. Urtti A, Pipkin JD, Rork GS, Sendo T, Finne U, Repta AJ (1990) Controlled drug delivery devices for experimental ocular studies with timolol. 2. Ocular and systemic absorption in rabbits. Int J Pharm 61:241-249

8. Hornof M, Toropainen E, Urtti A (2005) Cell culture models of the ocular barriers. Eur J Pharm Biopharm 60:207-225

9. Maurice DM, Mishima S (1984) Ocular pharmacokinetics. In: Sears ML (ed) Handbook of experimental pharmacology, vol 66. Springer, BerlinHeidelberg

10. Urtti A (2006) Challenges and obstacles of ocular pharmacokinetics and drug delivery. Adv Drug Deliv Rev 58:1131-1135

11. Von Sallman L, Meyer K, DiGrandi J (1944) Experimental study on penicillin treatment of ectogenous infection of the vitreous. Arch Ophthalmolgy 32:179-189

12. Daily MJ, Peyman GA, Fishman G (1973) Intravitreal injection of methicillin for treatment of endophthalmitis. Am J Ophthalmol 76(3):343-350

13. Homer P, Peyman GA, Koziol J, Sanders D (1975) Intravitreal injection of vancomycin in experimental staphylococcal endophthalmitis. Acta Ophthalmol (Copenh) 53(3):311-320

14. Forster RK (1974) Endophthalmitis: diagnostic cultures and visual results. Arch Ophthalmol 92:387-392

15. Peyman GA, Vastine DW, Crouch ER, Herbst RW (1974) Clinical use of intravitreal antibiotics to treat bacterial endophthalmitis. Trans Am Acad Ophthalmol Otolaryngol 78:862-875

16. Bernard H, Barza M (1994) Ceftazidime or amikacin: choice of intravitreal antimicrobials in the treatment of postoperative endophthalmitis. Arch Ophthalmol 112(1):17-18

17. Ozkiris A, Evereklioglu C, Kontas O, Oner AO, Erkilic K (2004) Determination of nontoxic concentrations of piperacillin/tazobactam for intravitreal application: an electroretinographic, histopathologic and morphometric analysis. Ophthalmic Res 36:139-144

18. Pathengay A, Mathai A, Shah GY, Ambatipudi S (2010) Intravitreal piperacillin/tazobactam in the management of multidrug-resistant Pseudomonas aeruginosa endophthalmitis. J Cataract Refract Surg 36(12):2210-2211

19. Singh TH, Pathengay A, Das T, Sharma S (2007) Enterobacter endophthalmitis: treatment with intravitreal tazobactam- piperacillin. Indian J Ophthalmol 55(6):482-483

20. Maurice DM, Mishima S (1984) Ocular pharmacokinetics. In: Sears ML (ed) Pharmacology of the eye. Springer, New York, pp 19-116

21. Meredith TA (2006) Intravitreal antibiotics. In: Glenn JJ, Ashton P, Pearson PA (ed) Intraocular drug delivery (Illustrated edition, 85-93). Taylor \& Francis, CRC, New York

22. Mitra AK, Anand BS, Durvuri S (2006) Drug delivery to the eye. In: Fischbarg J (ed) The biology of eye. Academic, New York, pp 307-351

23. Maurice DM (1976) Injection of drugs into the vitreous body. In: Leopold $I H$, Burns RP (ed) Symposium on ocular therapy, vol 9. Wiley, New York, pp 59-72

24. Barza M, Kane A, Baum J (1983) Pharmacokinetics of intravitreal carbenicillin, cefazolin, and gentamicin in rhesus monkeys. Invest Ophthalmol Vis Sci 24(12):1602-1606

25. Coco RM, López MI, Pastor JC, Nozal MJ (1998) Pharmacokinetics of intravitreal vancomycin in normal and infected rabbit eyes. J Ocul Pharmacol Ther 14(6):555-563

26. Öztürk F, Kortunay S, Kurt E (1999) Effects of trauma and infection on ciprofloxacin levels in vitreous cavity. Retina 19(2):127-130

27. Öztürk F, Kortunay S, Kurt E, Inan ÜÜ, IIlker SS, Bascı NE, Bozkurt A, Kayaalp SO (1999) Ofloxacin levels after intravitreal injection. Ophthalmic Res 31(6):446-451

28. Pearson PA, Hainsworth DP, Ashton P (1993) Clearance and distribution of ciprofloxacin after intravitreal injection. Retina 13(4):326-330

29. Peyman GA, Lee PJ, Seal DV (ed) (2004) Pharmacokinetics. Endophthalmitis: diagnosis and management. (Illustrated edition, 81-92). Taylor \& Francis. London

30. Maurice D (2001) Review: practical issues in intravitreal drug delivery. J Ocul Pharmacol Ther 17:393-401

31. Hegazy HM, Kivilcim M, Peyman GA, Unal MH, Liang C, Molinari LC, Kazi AA (1999) Evaluation of toxicity of intravitreal ceftazidime, vancomycin, and ganciclovir in a silicone oil-filled eye. Retina 19:553-557

32. Johnson F, Maurice D (1984) A simple method of measuring aqueous humor flow with intravitreal fluoresceinated dextrans. Exp Eye Res 39:791-805

33. Talamo JH, D'Amico DJ, Kenyon KR (1986) Intravitreal amikacin in the treatment of bacterial endophthalmitis. Arch Ophthalmol 104(10):1483-1485
34. Mandell BA, Meredith TA, Aguilar E, El-Massry A, Sawant A, Gardner S (1993) Effects of inflammation and surgery on amikacin levels in the vitreous cavity. Am J Ophthalmol 115(6):770-774

35. Galloway G, Ramsay A, Jordan K, Vivian A (2002) Macular infarction after intravitreal amikacin: mounting evidence against amikacin. Br J Ophthalmol 86(3):359-360

36. Choi S, Hahn TW, Osterhout G, O'Brien TP (1996) Comparative intravitreal antibiotic therapy for experimental Enterococcus faecalis endophthalmitis. Arch Ophthalmol 114(1):61-65

37. Wingard LB, Jr, Zuravleff JJ, Doft BH, Berk L, Rinkoff J (1989) Intraocular distribution of intravitreally administered amphotericin B in normal and vitrectomized eyes. Invest Ophthalmol Vis Sci 30(10):2184-2189

38. Barza M, McCue M (1983) Pharmacokinetics of aztreonam in rabbit eyes. Antimicrob Agents Chemother 24(4):468-473

39. Ficker L, Meredith TA, Gardner S, Wilson LA (1990) Cefazolin levels after intravitreal injection: effects of inflammation and surgery. Invest Ophthalmol Vis Sci 31(3):502-505

40. Shaarawy A, Meredith TA, Kincaid M, Dick J, Aguilar E, Ritchie DJ, Reichley RM (1995) Intraocular injection of ceftazidime: effects of inflammation and surgery. Retina 15(5):433-438

41. Unal M, Peyman GA, Liang C, Hegazy H, Molinari LC, Chen J, Brun S, Tarcha PJ (1999) Ocular toxicity of intravitreal clarithromycin. Retina 19(5):442-446

42. Schemmer GB, Driebe WT, Jr (1987) Posttraumatic Bacillus cereus endophthalmitis. Arch Ophthalmol 105(3):342-344

43. Koziol J, Peyman G (1974) Intraocular chloramphenicol and bacterial endophthalmitis. Can J Ophthalmol 9(3):316-321

44. Comer GM, Miller JB, Schneider EW, Khan NW, Reed DM, Elner VM, Zacks DN (2011) Intravitreal daptomycin: a safety and efficacy study. Retina 31 (6):1199-1206

45. Hernandez-Da Mota SE (2011) Quinupristin/dalfopristin in Staphylococcus aureus endophthalmitis: a case report. J Med Case Rep 5(1):1-3

46. Aydin E, Kazi AA, Peyman GA, Esfahani MR, Muñoz-Morales A, Kivilcim M, Caro-Magdaleno M (2007) Retinal toxicity of intravitreal doxycycline: a pilot study. Arch Soc Esp Oftalmol 82(4):223-228

47. Velpandian T, Narayanan K, Nag TC, Ravi AK, Gupta SK (2006) Retinal toxicity of intravitreally injected plain and liposome formulation of fluconazole in rabbit eye. Indian J Ophthalmol 54:237-240

48. Zachary IG, Forster RK (1976) Experimental intravitreal gentamicin. Am J Ophthalmol 82(4):604-611

49. Conway BP, Campochiaro PA (1986) Macular infarction after endophthalmitis treated with vitrectomy and intravitreal gentamicin. Arch Ophthalmol 104(3):367-371

50. Loewenstein A, Zemel E, Lazar M, Perlman I (1993) Drug-induced retinal toxicity in albino rabbits: the effects of imipenem and aztreonam. Invest Ophthalmol Vis Sci 34(12):3466-3476

51. Duke SL, Kump LI, Yuan Y, West WW, Sachs AJ, Haider NB, Margalit E (2010) The safety of intraocular linezolid in rabbits. Invest Ophthalmol Vis Sci 51(6):3115-3119

52. Fiscella R, Peyman GA (1988) Intravitreal toxicity of cotrimoxazole. Ophthalmic Surg 19(1):44-46

53. Aydin E, Kazi AA, Peyman GA, Esfahani MR (2006) Intravitreal toxicity of moxifloxacin. Retina 26(2):187-190

54. Desai S (1993) Ocular pharmacokinetics of tobramycin. Int Ophthalmol 17(4):201-210

55. Ng EW, Joo MJ, Au Eong KG, Green WR, O'Brien TP (2003) Ocular toxicity of intravitreal trovafloxacin in the pigmented rabbit. Curr Eye Res 27(6):387-393

56. Sa H, Hasset P, Bron AJ (2001) Intraocular vancomycin levels after intravitreal injection in post cataract extraction endophthalmitis. Retina 21:210-213

57. Gan IM, van Dissel JT, Beekhuis WH, Swart W, van Meurs JC (2001) Intravitreal vancomycin and gentamycin concentrations in patients with postoperative endophthalmitis. Br J Ophthalmol 85(11):1289-1293

58. Gan IM, Ugahary LC, van Dissel JT, van Meurs JC (2005) Effect of intravitreal dexamethasone on vitreous vancomycin concentrations in patients with suspected postoperative bacterial endophthalmitis. Graefes Arch Clin Exp Ophthalmol 243(11):1186-1189

59. Gao H, Pennesi ME, Shah K, Qiao X, Hariprasad SM, Mieler WF, Wu SM, Holz ER (2004) Intravitreal voriconazole: an electroretinographic and histopathologic study. Arch Ophthalmol 122:1687-1692

60. Mehta S, Armstrong BK, Kim SJ, Toma H, West JN, Yin H, Lu P, Wayman LL, Recchia FM, Sternberg P, Jr (2011) Long-term potency, sterility, and stability 
of vancomycin, ceftazidime, and moxifloxacin for treatment of bacterial endophthalmitis. Retina 31(7):1316-1322

61. Ta CN, Chang RT, Singh K, Egbert PR, Shriver EM, Blumenkranz MS, Miño de Kaspar H (2003) Antibiotic resistance patterns of ocular bacterial flora: a prospective study of patients undergoing anterior segment surgery. Ophthalmology 110:1946-1951

62. Yin VT, Weisbrod DJ, Eng KT, Schwartz C, Kohly R, Mandelcorn E, Lam WC, Daneman N, Simor A, Kertes PJ (2013) Antibiotic resistance of ocular surface flora with repeated use of a topical antibiotic after intravitreal injection. JAMA Ophthalmol 131(4):456-461

63. Dave S, Toma HS, Kim SJ (2011) Ophthalmic antibiotic use and multidrug-resistant Staphylococcus epidermidis: a controlled, longitudinal study. Ophthalmology 118:2035-2040

64. Kothuri MK, Pinnamaneni S, Das NG, Das SK (2003) Micro-particles and nanoparticles in dug delivery (437-66). In: Mitra AK (ed) Ophthalmic drug delivery systems. Marcel Dekker, New York

65. Mitra AK, Anand BS, Duvvuri S (2006) Drug delivery to the eye. Adv Organ Biol 10:307-351

66. Guidetti B, Azema J, Malet-Martino M, Martino R (2008) Delivery systems for the treatment of proliferative vitreoretinopathy: materials, devices and colloidal carriers. Curr Drug Deliv 5(1):7-19

67. Tsutomu Y, Ogura Y, Tabata Y, Kimura H, Wiedemann P, Honda Y (2004) Drug delivery systems for vitreoretinal diseases. Prog Retin Eye Res 23(3):253-281

68. Bochot A, Couvreur P, Fattal E (2000) Intravitreal administration of antisense oligonucleotides: potential of liposomal delivery. Prog Retin Eye Res 19:131-147

69. Cheng L, Hostetler KY, Chaidhawangul S, Gardner MF, Beadle JR, Keefe KS, Bergeron-Lynn G, Severson GM, Soules KA, Mueller AJ, Freeman WR (2000) Intravitreal toxicology and duration of efficacy of a novel antiviral lipid prodrug of ganciclovir in liposome formulation. Invest Ophthalmol Vis Sci 41:1523-1532

70. Eljarrat-Binstock E, Pe'er J, Domb AJ (2010) New techniques for drug delivery to the posterior eye segment. Pharm Res 27(4):530-543

71. Patane MA, Cohen A, Assang C, From S, Cohen A, Sugarman J (2010) Randomised, double-masked study of EGP-437 in subjects with non-infectious anterior segment uveitis. Poster presented at the American Academy of Ophthalmology annual meeting; October 16-19, Chicago

72. Bourges JL, Gautier SE, Delie F, Bejjani RA, Jeanny JC, Gurny R, Ezra DB, Behar-Cohen FF (2003) Ocular drug delivery targeting the retina and retina pigment epithelium using polylactide nanoparticles. Invest Ophthalmol Vis Sci 44(8):3562-3569

73. Ay GM, Akhan SC, Erturk S, Aktas ES, Ozkara SK, Caglar Y (2004) Comparison of intravitreal ceftazidime and meropenem in treatment of experimental pseudomonal posttraumatic endophthalmitis in a rabbit model. J Appl Res 4:336-345

74. Peyman GA, Conway MD, Fiscella R (2009) Interaction of intravitreal combination drugs and the effect on the targeted site. J Ocul Pharmacol Ther 25:387-394

75. Raju B, Bali T, Thiagarajan G (2008) Physicochemical properties and antibacterial activity of the precipitate of vancomycin and ceftazidime. Retina 28:320-325

\section{doi:10.1186/s12348-014-0022-z}

Cite this article as: Radhika et al:: Pharmacokinetics of intravitreal antibiotics in endophthalmitis. Journal of Ophthalmic Inflammation and Infection 2014 4:22

\section{Submit your manuscript to a SpringerOpen ${ }^{\circ}$ journal and benefit from:}

- Convenient online submission

- Rigorous peer review

- Immediate publication on acceptance

- Open access: articles freely available online

- High visibility within the field

- Retaining the copyright to your article

Submit your next manuscript at $\gg$ springeropen.com 